\title{
Exploring methodological approaches to assess climate change vulnerability and adaptation: reflections from using life history approaches
}

\author{
Chandni Singh ${ }^{1}$ (D) $\cdot$ Mark Tebboth $^{2,3} \cdot$ Dian Spear $^{4} \cdot$ Prince Ansah $^{5} \cdot$ Adelina Mensah $^{5}$ \\ Received: 5 October 2018 / Accepted: 13 September 2019 / Published online: 26 November 2019 \\ (C) The Author(s) 2019
}

\begin{abstract}
People in developing countries face multiple risks, and their response decisions sit at the complex and often opaque interface of climatic stressors, constrained resource access, and changing livelihoods, social structures, and personal aspirations. Many risk management studies use a well-established toolkit of methodologies - household surveys, focus group discussions, and semistructured interviews. We argue that such methodological conservatism tends to neglect the dynamic and differentiated nature of livelihood decisions. Since different methodologies privilege different portrayals of risk and response, we highlight how plural methodological approaches can capture a broader range of perspectives and problematisations. In this paper, we draw on life history (LH) interviews across four countries (Kenya, Namibia, Ghana, and India) to offer one way of expanding current methodological approaches on vulnerability and adaptation. We argue that LHs offer four key 'value additions'. First, LHs give insights into the multiple and interacting nature of drivers of response behaviour. Second, they highlight intra-household dynamics to demonstrate how people with differential power shape risk management decisions. Third, LHs support explorations of past decisions, present situations, and future aspirations, thus producing temporally nuanced enquiries. Fourth, they provide a powerful analytical lens to capture the interplay of motivations, aspirations, and values on livelihood choices and adaptation outcomes. By adding value in these four ways, LHs challenge assumptions about how and why people respond to multiple risks and offer a nuanced understanding of adaptation processes.
\end{abstract}

Keywords Lifehistories $\cdot$ Adaptation $\cdot$ Migration $\cdot$ Livelihoods $\cdot$ Vulnerability $\cdot$ Temporality $\cdot$ Risk perception $\cdot$ Risk management

Communicated by Shuaib Lwasa

Electronic supplementary material The online version of this article (https://doi.org/10.1007/s10113-019-01562-z) contains supplementary material, which is available to authorized users.

Chandni Singh

csingh@iihs.ac.in

1 Indian Institute for Human Settlements, Bangalore City Campus, No. 197/36, 2nd Main Road Sadashivanagar, Bangalore, Karnataka 560 080, India

2 School of International Development, University of East Anglia, Norwich, England NR7 4TJ, UK

3 Tyndall Centre for Climate Change Research, Norwich, UK

4 African Climate and Development Initiative, University of Cape Town, Geological Sciences Building, University Avenue South, Rondebosch 7700, South Africa

5 Institute for Environment and Sanitation Studies, University of Ghana, Box LG 209, Legon, Accra, Ghana

\section{Introduction}

Certain framings such as mathematical modelling, risk and impact assessment studies, and economic assessments have dominated climate change research (Ford et al. 2010; Bjurström and Polk 2011; Jurgilevich et al. 2017), driving it conceptually and methodologically. Several authors have called for pluralising the methodological approaches and languages we use to talk of, respond to, and prepare for climate change (Hulme 2011), highlighting potential contributions from disciplines such as geography (Hulme 2008), anthropology (Cutter 2003), and history (Adamson et al. 2018) in enriching discourses around climate change.

Climate change vulnerability and adaptation (CCVA) research, in particular, has been criticised for overlooking the dynamic nature of vulnerability, and how risks and responses interact to shape local adaptation (Ribot 2014; 
Bennett et al. 2016; Fawcett et al. 2017; Adamson et al. 2018). Studies are now demonstrating the value of using different methodological and epistemic bodies of work to address this: from case analogues to study temporal vulnerability (Ford et al. 2010; Fawcett et al. 2017), mixedmethods approaches for mapping shared socio-economic pathways (Birkmann et al. 2015), and narrative approaches for adaptation planning (Paschen and Ison 2014).

In this paper, we add to and extend this body of work by demonstrating the value of applying life history (LH) approaches to CCVA research. As part of a 5-year, multi-country, interdisciplinary project Adaptation at Scale in Semi-Arid Regions (ASSAR www.assar.uct.ac. za), we examined socially differentiated vulnerability and the role of migration in a household's suite of risk management strategies. To provide a counterpoint to the dominant methodological tools of household surveys and focus group discussions (FGDs) in environmental migration studies (Piguet 2010), we report our experiences of using LH interviews. We find that LHs examine migration and livelihood choices in a temporally sensitive manner that acknowledge climatic risks as one of the many factors affecting household responses (Bagchi et al. 1998; Nielsen and Reenberg 2010) and are a people-centred approach (Adger 2010) examining decision-making in risk-prone environments (AyebKarlsson et al. 2016). This paper charts our experiences and identifies the strengths and limits of using LH interviews for CCVA research.

There are three critical gaps in CCVA research that LH approaches can help fill. First, the insights on dynamic vulnerability and temporality that LHs offer are especially relevant when studying climate vulnerability, livelihood trajectories, and migration because they are dynamic and shaped by past experiences and future aspirations. Second, adaptation studies continue to focus on households as the appropriate unit of analysis without an equal emphasis on intra-household dynamics. Third, how people perceive risks and respond to them remains under-researched despite a growing acknowledgement of the role of risk perception in adaptation decisionmaking (Singh et al. 2016b; Burnham and Ma 2017). We argue that a LH approach enables us to, in part, address these gaps and expand the range of methodological options available to researchers.

In the subsequent sections, we review current methodological approaches used in CCVA research and their gaps (in 'Current methodological approaches to climate vulnerability and adaptation') followed by an overview of LH approaches and the research design we used (section on 'Life history approaches'). We then report from our experiences of applying a life history approach to climate change research. We end with a discussion on the the values and limitations of LHs to CCVA research.

\section{Current methodological approaches to climate vulnerability and adaptation}

\section{How have people studied vulnerability and adaptation?}

Vulnerability and adaptation research has a diverse conceptual legacy (Ford et al. 2010; Malone and Engle 2011; Joakim et al. 2015; Jurgilevich et al. 2017; Mortreux and Barnett 2017), moving from stressor-response approaches from hazard and disaster management studies (Füssel and Klein 2006) to livelihood approaches that articulated vulnerability as dependent on five capitals - human, social, natural, financial, and physical (Clay 2018). Poverty and development studies added to this by highlighting the importance of entitlements, capacities, and capabilities to vulnerability reduction (Sen 1981; Roy and Venema 2002; Adger 2006). Resilience studies went on to emphasise how multi-scalar linkages and cycles of repair and renewal shape vulnerability and adaptive capacity (Cannon and Müller-Mahn 2010; Tanner et al. 2014). From the social sciences, studies have focussed on the multiple, incremental drivers of vulnerability (O'Brien et al. 2004; Ribot 2014; Nyantakyi-Frimpong and Bezner-Kerr 2015), and value-based and justice approaches highlight how certain adaptation pathways can create winners and losers (Eriksen et al. 2011). More recently, a growing focus on linking risk perception and adaptation behaviour (Grothmann and Patt 2005; Nielsen and Reenberg 2010; Granderson 2014; Singh et al. 2016b; Burnham and Ma 2017) is beginning to explain how adaptive capacity leads to adaptation outcomes (Mortreux and Barnett 2017).

The conceptual diversity in CCVA studies also predisposes research to follow specific methodological approaches (Ford et al. 2010; Singh et al. 2017; Adamson et al. 2018). These include qualitative case study-based methods (Campeanu and Fazey 2014; Joakim et al. 2015), spatially mapping vulnerability hotspots (Varadan and Kumar 2015; Bouroncle et al. 2016), indicatorbased assessments (Hahn et al. 2009; Gupta et al. 2010; Gerlitz et al. 2017), participatory methodologies that co-produce adaptation solutions (van Aalst et al. 2008; Fazey et al. 2010; Howe et al. 2013; Ayantunde et al. 2015; Butler et al. 2016), and more recently, historical and temporal approaches to examine trajectories of change (Nielsen and Reenberg 2010; Fawcett et al. 2017; Adamson et al. 2018; Gajjar et al. 2018). This methodological diversity is detailed in Supplementary Material 1.

Within the umbrella of CCVA research, environmental migration (often identified as a key risk management and/or adaptive strategy in developing countries) is also explored through various methodologies that focus on temporality, livelihood choices, and household dynamics (Piguet 2010; Fussell et al. 2014; Neumann and Hilderink 2015; Arnall and Kothari 2015). Piguet (2010) identifies six families of environmental migration methodologies: spatial and multi-scalar analyses, large-N surveys, historical analogues, hotspots approaches 
using vulnerability indices, and qualitative field case studies using ethnographic methods. Migration research has also drawn on various disciplines with growing acknowledgement of the value of ethnographic (McHugh 2000), life history (Locke and Lloyd-Sherlock 2011; Singh 2018), and biographical (Erel 2007) approaches in understanding the "“quantum haze" of human mobility' (McHugh 2000:72).

The scholarship on environmental migration has conceptualised livelihoods as inherently dynamic, acknowledging multiple, multi-scalar drivers, where agency and structure interact and feedback on one another (Massey et al. 1999; Bardsley and Hugo 2010; Castles 2010; Bakewell 2010; Ransan-Cooper 2016). This has led to a methodological expansion where issues of identity, history, culture, and values are being examined more rigorously through qualitative methods focussing on temporality and migration decision-making (Piguet 2010; Ransan-Cooper 2016; Piguet et al. 2018).

\section{Gaps in the literature}

Several gaps remain in the current literature. First, there is increasing focus on understanding drivers of vulnerability and what mediates adaptation but relatively fewer studies exploring how these drivers of vulnerability interact to shape household response behaviour. Despite growing evidence of barriers to adaptation, there is a tendency to identify if there are barriers and describe which types they are (Biesbroek et al. 2013) rather than how they interact and shape responses. Several studies examine factors shaping adaptation, i.e. decision-making around climate change responses (van der Linden 2015), but quantitative approaches tend to mostly use large- $n$, structured surveys while qualitative approaches typically draw on semistructured individual or group interviews. While these approaches are useful to explain broad drivers of responses, they often give an inadequate understanding of individual decisionmaking (notable exceptions include Grothmann and Patt 2005; Nielsen and Reenberg 2010; Granderson 2014; Singh et al. 2016b; Burnham and Ma 2017).

There are growing calls for unpacking CCVA studies to understand the role of intra-household dynamics in mediating risk management choices and their outcomes (Djoudi et al. 2016; Rao et al. 2020). Empirical evidence from gender and feminist political ecology is filling this gap by focusing on intra-household bargaining and gendered vulnerability (Rao et al. 2020; Rao et al. 2017; Singh 2019), but these remain peripheral to mainstream CCVA research (Ravera et al. 2016; Thompson-Hall et al. 2016).

CCVA research in general and environmental migration in particular have also been critiqued for a relative silence on temporality (Obokata et al. 2014; Fawcett et al. 2017; Adamson et al. 2018) and overreliance on static methodologies such as household surveys to examine inherently dynamic processes such as adaptation (Singh et al. 2017). This counters growing evidence that household vulnerability is embedded in 'pre-existing precarity' (Ribot 2014: 673) and a result of complex structural conditions (Tschakert et al. 2013), which are often not captured by static, snapshot methodologies (Fawcett et al. 2017; Singh 2018). Different disciplines have used various approaches to study temporality such as case analogues, trend studies, pathways approaches, and oral histories (Supplementary Material 1). However, these methodological approaches tend to occupy a niche within CCVA studies. Cross-disciplinary work has recently broadened the methodological repertoire of CCVA research. For example, Adamson et al. (2018) forefront the role of historical approaches in developing long-term place-specific empirical studies, tracking institutional evolution to understand how historical events and decisions inform and constrain present adaptation, and providing a compass to follow discursive shifts and check historically grown power structures.

Finally, the implications of changing aspirations are seldom examined in adaptation research and practice. With growing recognition that adaptation is often about behavioural shifts (García de Jalón et al. 2015; Davidson 2016; van Valkengoed and Steg 2019), there is a need to understand how shifting aspirations mediate adaptation behaviour (Rao et al. 2020). Household surveys have been largely used to determine aspirations and motivation but usually do not capture intra-household dynamics and the context for individual aspirations within the household.

\section{Life history approaches}

\section{What are life history approaches?}

Life history (LH) approaches refer to a suite of approaches that typically involve open-ended interviewing to draw on life experiences and provide rich descriptions of a 'life as a whole' (Atkinson 2002, p. 123). Thus, LHs narrate not only life stories but also perceptions, memories, aspirations, and experiences that shape them (Elder 1998, 2012; Atkinson 2002; Chimhowu and Hulme 2006; Locke and Lloyd-Sherlock 2011; Wimark et al. 2017; Singh 2018). In doing so, they go beyond 'methods and approaches...defining and addressing problems' to examining 'the intersection of nature, humanity, and technology in multiple ways' (Moezzi et al. 2017).

LHs go beyond typical semi-structured interviews by focussing on narratives, i.e. exploring 'a sequence of events into a whole so that the significance of each event can be understood through its relation to that whole', thereby conveying 'the meaning of events' (Elliott 2005:3 in Lewis 2008). While semi-structured interviews can also capture temporality, they are relatively limited in emphasising how life events and key decisions are embedded in wider dynamics often beyond the individual's control (Singh 2019; Chimhowu and Hulme 2006; Singh 2018). LHs thus 'link personal experience with broader patterns of institutional change' (Lewis 2008: 561) connecting individual and the social (and at a conceptual level, structure, 
and agency) within the social sciences. Most critically, LHs reconfigure interviewer-interviewee power dynamics by placing value on peoples' perceptions of their life story (Locke and Lloyd-Sherlock 2011), thus 'humanising research' and giving 'history back to people in their own words, potentially rescuing it from dominant elitist discourses' (Thompson 1988: 265).

LHs have specific characteristics that are valuable for CCVA research. First, they delve into 'micro-historical (individual) experiences within a macro-historical (history of the time) framework' (Hagemaster 1992, p. 1122) thereby capturing cross-scalar linkages critical for household risk management (Adger et al. 2005; Osbahr et al. 2008; Eakin et al. 2009; Shucksmith et al. 2016). Second, LHs allow for a nuanced understanding of individual decisions that explain motivations and perceptions, challenging assumptions that decisions are discrete, rational choices (Hagemaster 1992; Atkinson 2002). This is in line with recent CCVA research that demonstrates the iterative, and multi-causal nature of adaptation decision-making (Grothmann and Patt 2005; Singh et al. 2016b; Burnham and Ma 2017). Third, LHs forefront the temporal nature of lives and livelihoods (Murray 2002; Locke and Lloyd-Sherlock 2011), giving insights into how household decisions are shaped by dynamic risks, changing aspirations, and consequent response pathways (e.g. Singh and Basu 2019; Singh 2019). This allows LH narratives to explore the dynamic contexts within which adaptation decisions were taken and can potentially help 'see' future decisions and identify entry points to shape adaptation behaviour. Critically, the focus on temporality goes beyond typical methodologies in livelihoods research that tends to be ahistorical (de Haan and Zoomers 2005) and assume risks and responses are static.

In development studies particularly, LHs have been used to examine poverty (Kothari and Hulme 2004; Bird and Shinyekwa 2005), well-being and economic empowerment (Locke and Lloyd-Sherlock 2011), and policy development and its implications (Chimhowu and Hulme 2006; Lewis 2008). Although LHs have 'now developed into a significant, theoretically dense, and diverse sub-set of historical and social-scientific enquiry' (Godfrey and Richardson 2004:144), they are not used in mainstream CCVA research which tends to be dominated by surveys, semi-structured interviews, and risk and impact modelling and assessments (see Supplementary Material 1).

There is a relatively small but growing body of CCVA research using LHs (or some form of them) to examine household trajectories of resilience and vulnerability (Bagchi et al. 1998; Murray 2002; Sallu et al. 2010; Shucksmith et al. 2016; Singh 2019; Singh \& Basu 2019), livelihood dynamics and their implications for household resilience (Rogaly and Coppard 2003; Ayeb-Karlsson et al. 2016; Singh and Basu 2019), and as a way to creatively understand and communicate climate concerns (Moezzi et al. 2017). These studies demonstrate that LHs go beyond case studies by 'providing respondents the chance to reflect on their own stories and report what they feel were crucial turning points rather than just submit a chronology of life events to be examined and interpreted by researchers' (Singh 2018 p., 3).

It is necessary to highlight that LHs are limited in certain ways - they are not amenable to generalisation (Lewis 2008) and cannot describe broad patterns in large populations. In 'the section Recognising the limits of life histories', we reflect on these limitations based on our experiences.

\section{Operationalising life histories: research design and data collection}

We draw on data collected in communities living in semi-arid regions of four countries; Ghana, India, Kenya, and Namibia. The research was part of a larger 5-year study, and while we report experiences of conducting research on migration, livelihood dynamics, differential vulnerability, and adaptation outcomes in this paper, other methodologies were used to capture dynamics in the wider social-ecological system. These other methods included structured household surveys (to capture demographic details, climate change perceptions, livelihood dynamics and risk management strategies, migration behaviour and well-being outcomes), and qualitative and participatory approaches such as group discussions, ${ }^{1}$ Vulnerability and Risk Assessment (Morchain and Kelsey 2016) and mental modelling (Rivers III et al. 2018). We do not describe each method in detail since it is beyond the scope of this paper but suggest references for those wanting to understand these approaches better.

In order to capture the diversity of households within the research locations, we used a purposive sampling strategy developed based on scoping visits and initial household surveys. The researchers iteratively co-developed a set of reasons to include/exclude households based on socio-economic characteristics, livelihood portfolios, and household composition and headship (Table 1). Based on these criteria, fifteen households were studied across the four sites.

Following the research objective (using narratives to understand how individuals within a household make response decisions, negotiate their risk landscape, and choose to migrate or not), the household was treated as a case and the main unit of analysis. Within each case, linkages were made to larger scales (institutional changes, biophysical dynamics) and finer dynamics (intra-households relations, well-being, and individual aspirations).

For this study, LHs were employed as a method to help examine changing relations of individuals within the household, set against the broader landscape of the community/

\footnotetext{
${ }^{1}$ The surveys used household-level structured questionnaires in India $(n=825)$, Kenya $(n=300)$, Ghana $(n=352)$, and Namibia $(n=647)$. Group discussions were carried out in India (26), Kenya (20), and Ghana (4). The discussions were segregated by men and women and typically discussed environmental change, climatic and non-climatic risks, livelihood shifts, and risk management strategies. The discussions tended to capture interhousehold and community differences and dynamics. In India, the discussions used timeline mapping to capture temporality but these were at community level (see Singh et al. 2016a).
} 
Table 1 Criteria used to sample households in the research sites

\begin{tabular}{|c|c|c|c|c|}
\hline Sampling criteria & India & Kenya & Namibia & Ghana \\
\hline Social characteristics & $\begin{array}{l}\text { Caste and religious group } \\
\text { (Hindu and Muslim) }\end{array}$ & Ethnic group (Boran, Meru) & $\begin{array}{l}\text { Ethnic group (Ovambo, } \\
\text { Himba, Onkumbi) }\end{array}$ & $\begin{array}{l}\text { Religious group (Christian, } \\
\text { Muslim) }\end{array}$ \\
\hline Household composition & $\begin{array}{l}\text { Male- and female-headed } \\
\text { households }\end{array}$ & $\begin{array}{l}\text { Male- and female-headed } \\
\text { households }\end{array}$ & $\begin{array}{l}\text { Male- and female-headed } \\
\text { households }\end{array}$ & $\begin{array}{l}\text { Male- and female-headed } \\
\text { households, widowed }\end{array}$ \\
\hline Type of movement & $\begin{array}{l}\text { Commuting, seasonal and } \\
\text { permanent migration, immobility }\end{array}$ & Mobility, immobility & $\begin{array}{l}\text { Permanent, semi-permanent } \\
\text { migration, and immobility }\end{array}$ & $\begin{array}{l}\text { Permanent, semi-permanent } \\
\text { migration, immobility }\end{array}$ \\
\hline Livelihood types & $\begin{array}{l}\text { Farming, non-farm wage } \\
\text { labour, petty business }\end{array}$ & $\begin{array}{l}\text { Agriculture, pastoral, } \\
\text { petty business }\end{array}$ & $\begin{array}{l}\text { Agro-pastoral, service industry, } \\
\text { petty business }\end{array}$ & $\begin{array}{l}\text { Farming, trading, } \\
\text { farming-trading }\end{array}$ \\
\hline Households sampled & 4 & 5 & 3 & 3 \\
\hline Individuals interviewed & 7 & 6 & 4 & 6 \\
\hline
\end{tabular}

socio-cultural context and larger institutional trajectories. Typically, two members within each household were interviewed to examine dynamics in their decision-making processes in relation to each other. In some cases, this was not possible due to local conditions. For example, in a Muslim household in India, the research team (female interviewer, male translator) was only able to speak to the male household head. Despite a good rapport built over several months, the team was unable to speak to the wife, in keeping with socio-cultural norms and the need to respect local sensitivities and customs.

We followed an open-ended interview process to explore personal accounts of the temporal nature of vulnerability, risks that their household (and they as an individual) are exposed to and how they respond, how and if mobility featured as a household response strategy, and perceptions of how well the household is doing. The LHs typically recalled changes over a 10-year period (some going further back to 30 40 years) and were split into three parts (preceded by the informed consent process). The first part generated quantitative data on the household. The second part was unstructured and focused on (1) significant life events and decisions undertaken, (2) changing household structure and decision-making, (3) shocks and stresses faced, and (4) reflections on drivers and outcomes of migration/immobility. The third part sought opinions on subjective and relational well-being, and individual and household hopes and aspirations for the future.

The interview transcripts and researcher notes were translated (where necessary) and transcribed. The transcriptions were coded by hand using a set of descriptive codes based on emerging themes from the interviews. The codes were co-developed between the researcher team through two workshops to facilitate comparative analysis. The four large code families were (1) description of livelihood dynamics (risks, responses, type of livelihood shifts), (2) intra-household dynamics and decision-making, (3) outcomes of responses (e.g. trade-offs, well-being outcomes), and (4) pathways (cycles of poverty, future aspirations). The analysis was an iterative and collaborative process, facilitated by the small dataset and intimate understanding all the researchers had with the context and households studied.

\section{Applying a life history approach to climate change research}

To examine the implications of the LH approach on CCVA research, we draw on multi-country data which examined household and intra-household risk perception and management, livelihood choices, and migration decision-making. In the following sections, we juxtapose findings from structured household surveys, FDGs, semi-structured group interviews (SGIIs), mental modelling, and participatory vulnerability assessments ${ }^{2}$ with data from LHs based on four themes: drivers of responses (why people act the way they do), intra-household dynamics and power relations, temporality (changes in livelihoods, risk portfolios and response strategies over time), and aspirations.

\section{Drivers of responses}

The household surveys were useful in drawing patterns of livelihood shifts and the role of migration within them. For example, in South India $(n=825)$, we found $39 \%$ households migrated ( $81 \%$ of these being men) in search of better jobs (56\%), to escape unprofitable agriculture $(26 \%)$ and to overcome debt (8\%). These patterns were one-time snapshots of livelihood decisions and did not examine how household responses to dynamic risks change over time. When discussing risks within the survey, respondents were asked yes or no questions on risks they faced and their relative importance, which helped understand what risks were faced but not why and how.

In Namibia, the survey $(n=647)$ recorded shocks people experienced (from a list of 20, determined through previous scoping visits and participatory rural appraisal methods) and responses undertaken using a list of 'coping strategies'. The data

\footnotetext{
${ }^{2}$ In the four countries, information was collected from group discussions in India and Kenya, mental modelling and FGDs in Ghana, and FGDs and participatory Vulnerability and Risk Assessments (VRA) in Namibia.

${ }^{3}$ These included sell assets, sell livestock, use savings, remittances, aid from $\mathrm{NGO}$, relied on government support, borrowing money/loan, seek other type of work, cut meals/less preferred food, grazing in forest/national park, invest more time looking for pasture, exchange goods/ barter, moved from home to look for work, and doing nothing.
} 
showed that early maturing crops $(66 \%)$, changing timing of planting (68\%), and spatial planning (15\%) were the most common coping strategies for crop farming, while supplemental feeding (51\%), moving livestock (26\%), destock (11\%), and changing herd mix (11\%) were the most common coping strategies for livestock farming. In this way, the survey captured the range of response strategies households employed but did not explain the drivers behind these choices. In the LH interviews, all strategies were seldom discussed but those discussed were better able to capture detailed motivations behind response decisions, the decision-making process, and outcomes of responses. Some of these 'value additions' that LHs provided compared with structured household surveys are explained in Table 2.

The LHs also served to highlight how multiple risks are experienced and intersect to shape daily realities. For example, a 48-year-old man who commuted between his village and a large city in India said,

Growing up, I have seen my father struggle to feed the family. The only way he could do so was by incrementally selling off his land... I dropped out of school very early and became a wage labourer to supplement my family's income... People can make as much money in the village as they do in the city. However, there are social constraints. Caste is the main one; it governs ... what circles you are part of, what livelihoods you are allowed to practice, what support and opportunities you can access, and ... what things you can acquire for yourself and your family... I commute to Bangalore daily and work there as a gardener...At least my children have finished secondary school and can support themselves and the family, if needed. [IND1]

The quote captures the trajectory and sequence of risks and responses experienced and how they shape his and his children's lives. While his father responded to food insecurity by selling the family land, he diversified first by becoming a wage labourer and then commuting to Bangalore city for work. Looking forward, he notes that these choices shape the opportunities his children have, through education. In the interview, he also alluded to how broader socio-cultural norms (caste) and assets (social networks) play a role in managing risk.

The second form of data from group discussions tended to allow for more detailed discussions on intersecting drivers of responses. ${ }^{4}$ The gender-segregated discussions also provided insights into what men and women do and why. These narratives were typically at community scale (thus often capturing interhousehold dynamics but masking intra-household dynamics). For example, in Kenya, the group discussions with pastoral communities were segregated by age and gender. Older men reported loss of different types of fodder due to erratic and low rainfall

\footnotetext{
${ }^{4}$ See Supplementary Material 2 for details on data from LHs versus other qualitative tools.
}

exacerbated by overgrazing. Issues of reduced fodder were compounded by ongoing, low-level ethnic conflict (between the Meru and Borana) that has limited access to local markets, forcing people to travel further. Cumulatively, these pressures have affected businesses, like miraa ${ }^{5}$ trading, since producers, middlemen, and customers now travel longer distances to access markets. In contrast, younger men highlighted that long dry spells affected miraa prices, with grave consequences for youth reliant on it as a livelihood, while women noted that the severe drought in 2011 led to acute pasture shortage, lack of water, and widespread livestock deaths. Thus, the group interviews constructed a picture of biophysical risks constraining local livelihood systems.

Let us now examine the findings from the LHs. In Kenya, for example, a widowed woman who runs a small shop and trades fruit, vegetables, miraa, and other household products reported that ethnic conflicts meant that she had to rely on miraa stock she had. The ethnic conflict had disrupted water availability from the mountains (provided through tankers), making her rely on bottled water $(\$ 0.50$ for 11$)$ or buying water from the police $(\$ 0.30$ for 201 ). In another LH, a 27 -year-old father of four children lives and works in Isiolo, Kenya, primarily as a construction labourer. Having previously owned a small herd of sheep, he reported how the severe drought of 2011 left very little pasture, forcing him to move his sheep farther. By the time rains came, his two remaining sheep were so weak that they also died. During this period, he often resorted to buying fodder he could ill afford and his wife would collect vegetable scraps from nearby houses and the local market for the sheep. At the height of the drought, his wife's small business of buying and selling vegetables provided their only income. Thus, the LHs alluded to biophysical risks and ethnic conflicts but added experiences of interactions between multiple risks, responses, and how these were sequenced.

A third form of data was collected through participatory exercises such as community-scale VRAs. VRA exercises were conducted as workshops, focusing on the entire socialecological landscape, to build and strengthen relationships between stakeholders and enable marginalised voices to be heard (Morchain and Kelsey 2016). In Namibia, participatory, multi-stakeholder VRA workshops were conducted to analyse multi-scalar causes of vulnerability (Hegga et al. 2016).

The VRA workshop provided critical insights into beyondcommunity drivers of vulnerability and responses. For example, as expected, drought and erratic rainfall were the highest ranked risks. Other drivers of vulnerability were 'cultural beliefs stopping new practices' (ranked third) and institutional and informational issues (e.g. limited availability of climate forecasts and limited agricultural extension services ranked fourth and fifth, respectively) (Hegga et al. 2016). By bringing together multiple stakeholders and using a system approach, the VRA results explored structural drivers of vulnerability such as historic inequalities and

\footnotetext{
$\overline{5}$ A plant native to the Horn of Africa and the Arabian Peninsula, that, when chewed, acts as a stimulant; also known as Khat or Qat
} 
Table 2 Value added by life histories across the four research sites

\begin{tabular}{|c|c|c|}
\hline Themes & Data collected by household surveys and life histories & LH value additions \\
\hline $\begin{array}{l}\text { Drivers of response } \\
\text { behaviour-why } \\
\text { do people do what } \\
\text { they do? }\end{array}$ & $\begin{array}{l}\text { The survey provided a snapshot of risks and responses through yes/no questions. } \\
\text { While reasons for a response strategy were ascertained (e.g. by correlating } \\
\text { with other socio-economic variables), interactions between risks and responses } \\
\text { (i.e. sequencing, what were the tipping points) were difficult to draw out. } \\
\text { LHs highlight the dynamic nature of responses (how shocks can compound over time, } \\
\text { how households follow response pathways i.e. where you come from can indicate where } \\
\text { you are headed), and the differential responses at an intra-household scale. }\end{array}$ & $\begin{array}{l}\text { - Sequence of risks and responses } \\
\text { - Multi-causal nature of risks } \\
\text { - Interactions of risks and responses } \\
\text { to shape household trajectories } \\
\text { - Differential responses at } \\
\text { intra-household level }\end{array}$ \\
\hline $\begin{array}{l}\text { Intra-household } \\
\text { dynamics and } \\
\text { power relationships }\end{array}$ & $\begin{array}{l}\text { The surveys captured information on household structure, member contributions, } \\
\text { and decision-making. However, the survey only elicited information from one } \\
\text { member of the household, getting only one perspective (except in Kenya } \\
\text { where surveys were done with two members in a household and examined, to } \\
\text { some extent, bargaining power and intra-household differences). Data on } \\
\text { intra-household dynamics and power relationships were difficult to capture. } \\
\text { The LHs gave information on household dynamics and different perspectives from } \\
\text { different household members including on intra-household trade-offs. }\end{array}$ & $\begin{array}{l}\text { - Shifts in intra-household work } \\
\text { burdens, bargaining power } \\
\text { - Insights on different opinions and } \\
\text { agency within households }\end{array}$ \\
\hline Temporality & $\begin{array}{l}\text { The surveys captured temporality through recall questions; e.g. reporting present } \\
\text { poverty, well-being and satisfaction and how it had changed from ten years ago } \\
\text { (in India, Namibia), changing perceptions of risk (rainfall variability, food security } \\
\text { in Ghana, India), or examinations of past decisions (Kenya). While answers } \\
\text { indicated changes, they did not explain how that change occurred and why. } \\
\text { Through the LHs, household and intra-household narratives emerged, } \\
\text { demonstrating shifts in risks, well-being over time. }\end{array}$ & $\begin{array}{l}\text { - Change and temporality of risks } \\
\text { and responses } \\
\text { - Relationships between changing } \\
\text { risks and dynamic responses } \\
\text { - Link between past decisions and } \\
\text { future aspirations }\end{array}$ \\
\hline $\begin{array}{l}\text { Interplay of motivations, } \\
\text { aspirations, resentments, } \\
\text { and values on livelihood } \\
\text { choices }\end{array}$ & $\begin{array}{l}\text { This was absent from the survey in all four research sites. In India, there was an } \\
\text { open-ended question on hopes for the future but the data were not robust enough } \\
\text { for analysis. In Namibia, hopes for the future were captured on a Likert scale } \\
\text { (from } 1=\text { Not hopeful at all to } 10=\text { Very hopeful). While this gave an indication } \\
\text { of hopes for the future, it did not elaborate on what these hopes were and whether } \\
\text { people thought they could be realised or not. } \\
\text { In the LHs, aspirations were prominently discussed. For example, in India, female } \\
\text { respondents spoke of resentments around not being able to migrate because of } \\
\text { gendered norms of work and care duties. }\end{array}$ & $\begin{array}{l}\text { - Elaboration of future aspirations } \\
\text { at intra-household level }\end{array}$ \\
\hline
\end{tabular}

long-standing lacunae in governance systems. This was more holistic than in LHs where some of these aspects were referred to, but their role in mediating responses was not always clear. The VRA also involves a step called 'Aligning Findings with Opportunities' which is a solution-oriented forward-looking exercise. Through this, the VRA workshops developed response strategies based on identified vulnerabilities or impacts, giving critical insights into local needs and possible priority areas.

One drawback of the VRA was that the exercises did not focus on temporality; risks and responses were listed as static options rather than dynamic entities. ${ }^{6}$ Morchain and Kelsey (2016, p. 7) note that 'considering the increasing complexity of landscapes and the people inhabiting them, a VRA should be repeated roughly annually or biannually, or when important changes take place. This will ensure the findings reflect the latest dynamics' (emphasis in original). Such a reflection highlights that dynamics are important but given multiple strands of inquiry participatory exercises already have,

\footnotetext{
${ }^{6}$ It is important to note that the VRA workshops could have been adjusted to capture temporality and dynamic risks and responses. However, participatory VAs are constrained by having multiple objectives and the usual constraints of group exercises (e.g. limited time to conduct multiple exercises, significant skill requirements, and the need to keep exercises inclusive when conducted in heterogeneous groups) (van Aalst et al. 2008).
}

dynamic risks and responses often get overlooked or reduced to checklist type assessments. Further, participatory risk assessment exercises require significant time and skill (van Aalst et al. 2008). However, with its focus on equity and agency, the VRA proved to forefront marginalised voices and concerns more than standard group discussions or LHs.

\section{Intra-household dynamics and power relationships}

Intra-household gender relations are critical to shaping individual vulnerability and response strategies to manage risk (Rao et al 2020; Singh 2019; Ravera et al. 2016; Rao et al. 2017). Based on relative capacities, work burdens, and agency, individuals within a household negotiate different risks differentially, either towards maintaining or enhancing overall household well-being or to consolidate their relative position (Singh and Basu 2019; Rao 2014; Ngigi et al. 2017; Rao et al. 2020).

The LHs helped unpack intra-household dynamics relatively well. By interviewing multiple people within the household, LHs captured (1) trade-offs between household members, (2) how risk perceptions were differentiated by position within the household, and (3) how response strategies were coproduced by household members as well as shaped by individual agency and voice (e.g. 
see Case Study 1). Insights on iterative negotiations underpinning household decisions were absent from the survey data, which typically collected data from one household member (usually the household head) and did not adequately cover power differentials within the household unit. The survey in Kenya was an exception where two members within each household, the household head and a member of the opposite gender, were interviewed, which led to a more nuanced dataset on intrahousehold dynamics.

\title{
Case Study 1 Intra-household trade-offs
}

\begin{abstract}
Trade-offs: LHs give insights into intra-household dynamics and trade-offs. For example, in Kenya, male migrant reported spending 3-4 days/week taking livestock to market. During this time, his wife had to spend an equivalent amount of time with the herd making it difficult for her to care for her children and relatives as well as pursue her own petty trading. Thus, the mobility necessary to look after her husband's livestock was balanced against caring requirements and other livelihood activities. In contrast, a female respondent who had relocated from a small rural settlement to Isiolo to support her husband's miraa business. She reported that was against the move and would still prefer to return to her 'home' village as she has struggled in Isiolo with the higher costs of urban living and feelings of loneliness and isolation.

In India and Namibia, there were examples of movement of some household members curtailing the movement of others. For example, a 48-year-old Indian farmer who commuted daily to work in Bangalore city noted that his moving meant that his wife and elderly mother had to stay behind to look after crops, livestock, and other family members. In Namibia, caregiving for the elderly meant some household members could not move. As a 26-year-old man elaborated,

... "my grandmother was staying alone in the house and I came to assist her with livestock and to work in the field" ... "I will be able to go (migrate), provided that, if by chance, there will be someone who will come to help look after the livestock and give a hand to the grandmother" ... "they are only supporting me because I am looking after the grandmother but if happen to go somewhere else then they will support me but not the same way as I am staying at home" ... "There will be some who will support the idea of me going but on the other hand, some family members will not want me to leave, with the reason that no one will actually stay with my grandmother" [NAM 2].
\end{abstract}

The quote highlights how intra-household trade-offs have implications on individual mobility, a fact that is often masked in other forms of data. Further, he alludes to receiving reciprocal support from his family in lieu of fulfilling family obligations. Such intangible aspects shaping decisions to move or not are critical to understand migration behaviour.

Voice and agency: Another aspect of intra-household decision-making captured through the LHs was differential agency within the household. For example, from Ghana, a 25-year old man said,

"After one farming season, I requested (for) permission from my aunty to go to the city and do labour work but I couldn't go because she wasn't happy about my decision. I could have gone without her consent but I suppose that was not the right thing to do after all she has done for me as a guardian" [GHA6].

This quote demonstrates how individuals negotiate personal aspirations and familial expectations to make decisions to move or not. Thus, normative factors such as perceived obligations and one's relative age, shape migration decisions, in addition to the usually reported drivers such as drought, financial resources, and social networks. Such an understanding sheds light on adaptation decision-making, which remains an underresearched area.

In Ghana, mental modelling was also used to understand how households deal with food insecurity. Semi-structured interviews were done with young and old, men and women. Mental modelling interviews involved inviting respondents to talk about their experiences of food access and management without interruption or probing. The data were analysed to establish recurring themes and relationships and construct a model influence diagram to understand experiences of food security differentiated. The mental modelling data provided rich insights into why people respond the way they do (drivers of responses) with implications for understanding inter- and intra-household response behaviour. However, it did not show how experiences with food security change over time, although some dynamics were established during analysis.

The LHs drew out how food security (especially access) is shaped by multiple factors such as drought incidence, household structure, dependence on relatives, and changes over time. For example, members in one household traced how the death of the head affected food access and availability:

'The family of my late husband took all the properties I had including the farmland. This was when I was 
already suffering. They took the livestock and the harvest we had including 30 pigs, 20 guinea fowls, 7 bags of beans, 6 bags of corn and 7 bags of rice. This made living conditions difficult for me and my children. We couldn't even have two-square meals in a day'. (GHA3)

We found that mental modelling interviews collected rich data on individual roles in maintaining household food security and captured differentiated food access at inter- and intra-household levels. However, given the uninterrupted format of interviewing, key risks and responses were often left out and how access changed over time was inadequately captured. The LHs filled this gap by collecting information on a household's specific context, relationships between household members, and their roles within or around a particular activity (e.g. securing food), over time.

\section{Temporality}

How risks, vulnerability, and peoples' responses change over time is a key question in CCVA research and one that has been repeatedly identified but have relatively low empirical evidence (Fawcett et al. 2017; Adamson et al. 2018). In our research, the survey typically captured temporality (of risks and response outcomes) through recall questions. For example, dynamic risks were explored through perceptions of change in rainfall variability, access to fodder, or water availability. Responses were captured through before/after questions. In Namibia, Ghana, and India, the survey included questions on levels of poverty and changes in subjective wellbeing presently and 10 years ago. The LHs dealt with temporality - past decisions, present situations, and future aspirations - in detail. The pathways households took were easy to follow since most of the interviews captured risks as they had occurred, and actions taken in response to those risks (Case Study 2). In doing so, the LHs often highlighted how several risks can be sequenced together leading to a compounding of effects, while at other times different responses (even from different household members or external actors) can come together to strengthen household responses (these findings are reported in a forthcoming paper by Tebboth et al.).

Case Study 2 Temporality and risk and response pathways

One of the strengths of a LH approach lies in its ability to capture sequences of cause and effect in individual lives. More specifically, LHs help reveal the interaction between structural elements (such as political considerations or social norms) and more individual or personal goals and perceptions of the world (Bertaux \& Thompson 1997 in Thomson et al. 2002). In Namibia, Kenya and India, the survey data explored change over time in economic status and subjective wellbeing. These measures provided some idea of change but almost no insight on the (perceived) drivers of this change. In contrast, LH data collected in the same locations (although not statistically generalizable), provides more depth, a thicker description that Geertz (1973) talks about (see Figure 2). Through this method we can see wider structural factors that impinge on and shape individual decisions and trajectories of wellbeing.

Figure 2: Life course of KEN2.

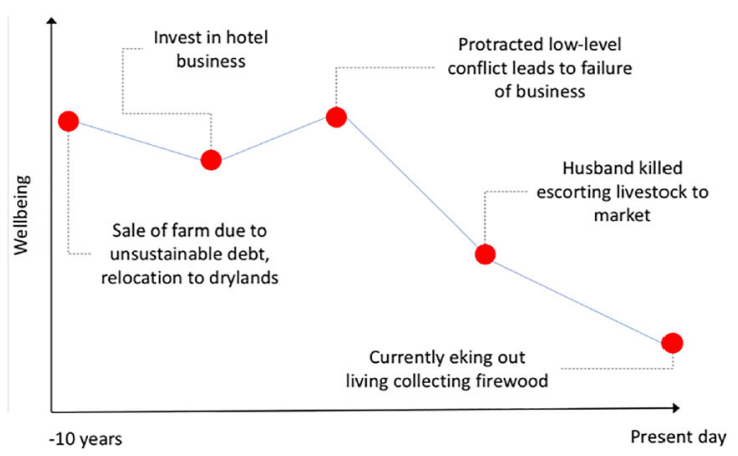

Survey data were also collected on household actions in response to shocks and highlight several measures such as selling assets, using savings, and seeking other livelihoods. However, the insights tended to lack a contextual understanding to help appreciate what selling assets actually entails. To use the example above, KEN2 and her husband sold their farm which would be listed as one category of response within a survey but the implications of that decision and the reasons why it is necessary remain masked. The data generated through the LH highlights how the sale did not positively impact the family's wellbeing and repeated shocks thereafter pushed them into further destitution. This more contextual understanding highlighted the various ways individuals respond to dynamic risks they experience over the course of their lives. 
While the group discussions captured changes in risks and responses over time, they tended to be reported as discrete events and seldom captured pathways of responses the way the LHs do. In India, the FGDs used participatory timeline exercises to follow trajectories of biophysical, social, institutional, and political changes (methodological details in Singh et al. 2016a). The 45-year timelines (from 1970 onwards) identified specific risks and consequent responses people had undertaken. The data captured broad changes with specific events signposted, such as significant droughts or large development projects. In contrast, the LHs also alluded to these broader changes but demonstrated how these events had led to specific household/individual responses and gave insights into how reactive and proactive approaches were undertaken. Further, they allowed us to construct household response pathways (as shown in Case Study 2) where households followed certain trajectories as a result of the risks faced and responses taken.

\section{Motivations and aspirations}

Aspirations are examined in poverty and social mobility studies (Ray 2006) but seldom discussed in CCVA research (Rao et al. 2020). Understood as 'conceptions of how human beings engage their own futures' (Appadurai 2004: 33), aspirations are integral to livelihood decisions such as whether to migrate or not (Suckall et al. 2016; Scheibelhofer 2017), changing labour practices and social norms (Punch and Sugden 2013), and when dealing with socio-ecological transitions in rural areas (Rigg 2006).

In India and Namibia, the surveys ended with a question on aspirations, captured through what people aim to invest in and what their hopes were for the future. As a standalone block at the end of a lengthy survey, this did not work well and the data were not robust enough to be analysed. The LHs were able to weave questions on aspirations into the broader interview, as a story spanning the past, present, and future rather than a standalone question which can be unrepresentative of lived realities.

We found that aspirations typically involved wanting to educate children (education being seen as a vehicle of upward social mobility), improve existing livelihoods (e.g. invest in improving farming), and in some cases return to one's home (e.g. several permanent migrants in India spoke of returning 'home', to their villages after earning in the city). These rich narratives of aspirations not only explained what people looked forward to and hence valued but also allow glimpses into what motivates people and hence can incentivise behavioural change towards adaptation. Moreover, we can see how aspirations differ for different elements of people's lives (for children, livelihoods, safety etc.), holding critical insights into what motivates individuals to undertake different responses.

\section{Recognising the limitations of life histories}

There, of course, remain caveats to the LH approach. The narrative data LHs generate cannot be read in a vacuum; the life stories are deeply embedded in wider socio-political environments and dynamics, and analysing this requires intimate understanding of local and wider contexts. Linked to this is the need for advanced qualitative analysis skills to make sense of narrative data. In our research, we overcame this constraint by having experienced and novice qualitative researchers work collaboratively from research conceptualisation to data analysis with regular discussions on how to conduct open-ended interviews, record data, and analyse and write up the narratives (summarised in Davies et al. 2018).

There are certain drawbacks inherent to the process of LH interviews themselves. These include the costs and barriers of accessing respondents, time required to collect and analyse data, and risk of gatekeepers shaping data quality. ${ }^{7}$ Often, LH interviews suggest a number of livelihood decisions, and interviewers must choose one or a few as examples to follow up in detail in the interview in the interest of time and respondent attention. While these can be mitigated by following good practices from ethnographic traditions (for example, immersion in the research site, triangulating data, and rapport building with respondents), they remain time-consuming processes that require significant skills.

While LHs reconfigure researcher-respondent hierarchies, they still rely on the researcher to frame the narrative and decide what parts of the story are reported, highlighting the 'power of authorial control' (Lewis 2008, p. 562). In our study, we overcame this to some extent by staying as close to the narrative as possible and minimising reinterpretation on the researcher's part.

LHs are often criticised for the difficulty of generalising from individual, highly granular data. Here, it is important to revisit what LHs set out to do - they create 'multiple and diverse 'little narratives' that contest 'the stability of received knowledge' (Gardner 2002: 28). Thus, generalisation is not a core aim of LH data. However, given that generalisation is an important concern, especially when the research is meant for policy audiences that require the big picture, some studies have shown how LH data can be used to provide an understanding of broader 'types' and patterns. For example, examining changing well-being of older people in Buenos Aires, Locke and Lloyd-Sherlock (2011) analysed commonalities and differences in how informants referred to particular relationships, turning points, or changes in circumstances. In their analysis, they focused on contrasting pairs of narratives (around a particular theme) in detail and followed with a brief, generalised account of how that theme appeared in the wider

\footnotetext{
${ }^{7}$ These challenges are not unique to LHs and are commonly encountered in other qualitative methods too.
} 
group. This allowed preserving 'the integrity of individual life histories whilst enabling us to explore the variety of experiences of linked lives' (p. 1137).

Finally, LHs can suffer from a 'biographical inevitability paradox ${ }^{8}$ as they are always told from the position of the interviewee today. Thus, they can be criticised for being self-justifying narratives that attempt to explain current situations (good or bad) with the benefits of hindsight. Respondents can hide and reveal certain stories, thus showing what they want you to see (Baumeister and Newman 1994). In this sense, what people say about their lives may not be considered by positivist researchers as 'true' in the objective sense. We did encounter examples of interviewees manipulating stories, masking certain aspects, or giving conflictive narratives. However, we argue that these silences and manipulations can allow CCVA researchers understand what people value and how that drives their decision-making. More importantly, conflicting narratives can often allow insights into the process of sense-making of precarious lives (Granderson 2014). Such a focus uncovers some of the myths of climate change, such as the view that it is a primary driver of livelihood decisions, and highlights the plurality of views about a single event, a specific stressor, or a particular intervention.

\section{Discussion and conclusion}

As the scope of CCVA research has expanded from climate modelling and impact assessment, to more qualitative explorations of how and why some people adapt to climate change, the methodological approaches used have also expanded. In this paper, we began by reviewing the methodological landscape of CCVA and found there remain gaps in linking risk perception to decisions people make about their livelihoods and managing risk ('Current methodological approaches to climate vulnerability and adaptation' section). While each methodological approach has its own strengths and weaknesses (and it is not our aim to elevate one over the other), in this paper, we argue that life histories (LHs) add value to CCVA research in several ways.

First, a life history approach examines temporality and demonstrates that household livelihoods and risk management strategies are not static. They are dynamic and continually adjusted in response to external changes (of which climate change is one) and internal dynamics (changing household configurations, aspirations, asset bases etc.). LHs acknowledge and capture how people use 'social navigation' (Langevang 2008) to respond to and prepare for an environment and socio-institutional context that is constantly changing. In doing so, we respond to calls for " "time-scape" investigations into the ways individual citizens construct ideas of

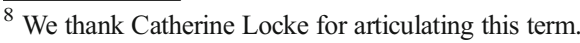

climate' (Hulme et al. 2009) and offer LHs as an approach to strengthen evidence on temporality in CCVA research.

Second, by demonstrating the processes households undertake to respond, the fixation of articulating causal links between migration and climate change falls apart. Research on environmental migration has evolved from alarmist discourses that envisioned climate change driving environmental refugees to a focus on ascertaining the role of climate change among other, more structural drivers of mobility such as lack of opportunity, conflict, or poverty (Bettini and Gioli 2016; Gemenne and Blocher 2017). Despite growing acknowledgement of this non-linear, complex landscape of migration decision-making (Farbotko et al. 2018), methods to understand how environmental drivers interact with other socioeconomic factors are 'nascent' (Bettini and Gioli 2015:7) and rarely pluralistic (Baldwin and Fornalé 2017; Piguet et al. 2018). Against this gap, LHs appear to be a valuable approach to refocus environmental migration research away from causation alone to a more bottom-up, inclusive understanding of how people operate within webs of risks and responses.

Third, a life history approach captures the complexity and messiness of household decision-making and highlights how different people within the same household have different motivations, thus unpacking intra-household dynamics. It forefronts how certain combinations of characteristics, e.g. age, gender, and educational qualifications, can come together to mediate risk management. It can also demonstrate how focussing on households as homogenous units tends to mask tradeoffs that individuals make (as shown in Case Study 1). We argue that the intra-household data that LHs collect can add to the growing field of gender and adaptation, thereby increasing the voices and views that are represented in CCVA research. At a larger, policy-facing scale, this has implications on what is seen as effective adaptation and who is included in shaping discourses on effectiveness.

Fourth, the granularity that $\mathrm{LHs}$ provide add depth to vulnerability and adaptation studies moving away from a 'pressure and release model' (Blaikie et al. 2004) to one of iterative decision-making marked by non-linearity and trial and error. In writing about human vulnerability and environmental change, McLaughlin and Dietz (2008:99-100) argue that further progress will only be achieved if researchers '...develop a more robust, integrated perspective on vulnerability, one capable of addressing the interrelated dynamics of social structure, human agency, and the environment'. We believe LHs can add to this agenda of building empirical evidence around the dynamic and interlinked nature of household risks and responses.

Fifth, LHs forefront the importance of perceptions (of risks and well-being) and add to the literature on how risks are perceived and go on to shape responses. By capturing 'lived experience or embodiment of risk' (Granderson 2014:57), LHs potentially democratise the sensemaking of risks, showcasing that there is no one 'truth'. Capturing the subjective, 
Table 3 Practice and policy implications of life history data

\begin{tabular}{|c|c|c|}
\hline Assumptions & Insights from LHs & Implications for adaptation practice, policy \\
\hline $\begin{array}{l}\text { Households are the appropriate unit } \\
\text { for adaptation interventions }\end{array}$ & $\begin{array}{l}\text { Differential vulnerability, risks, responses, and } \\
\text { their impacts on adaptive capacity vary within } \\
\text { households }\end{array}$ & $\begin{array}{l}\text { The household as a unit for adaptation (and development) } \\
\text { interventions may not always be appropriate. To be } \\
\text { effective and inclusive, some interventions, especially } \\
\text { those aimed at meeting development needs and have } \\
\text { ratcheting effects on adaptive capacity, can be targeted at } \\
\text { women or young men especially. }\end{array}$ \\
\hline $\begin{array}{l}\text { Provision of technical solutions (e.g. } \\
\text { drip irrigation, drought-tolerant } \\
\text { seeds) is sufficient to adapt }\end{array}$ & $\begin{array}{l}\text { Provide detailed evidence of perceptions of risks } \\
\text { and motivations to adapt that are often } \\
\text { personal, non-climatic, and dynamic }\end{array}$ & $\begin{array}{l}\text { The data from LHs can give insights into why people adapt } \\
\text { or not. This can also be used to target policy and make } \\
\text { uptake of adaptation interventions more effective. }\end{array}$ \\
\hline $\begin{array}{l}\text { One-time vulnerability assessments } \\
\text { can adequately inform adaptation } \\
\text { practice }\end{array}$ & $\begin{array}{l}\text { Enable developing household response } \\
\text { pathways/trajectories to visualise how vulner- } \\
\text { ability is dynamic }\end{array}$ & $\begin{array}{l}\text { Data from LHs can be possibly used to understand when to } \\
\text { intervene. For example, Singh \& Basu (2019) describe } \\
\text { how some households follow upward or downward } \\
\text { trajectories, and such data can be potentially used to } \\
\text { nudge upward households to do better and provide safety } \\
\text { nets for downward households to improve. }\end{array}$ \\
\hline
\end{tabular}

contextual, and dynamic nature of risk perceptions, this differentiated understanding of risk perception can help explain where interventions can potentially be most effective and how uptake can be incentivised.

LHs can also offer insights to adaptation practice and policy which challenge conventional 'givens' (Table 3). While these implications can be drawn from other methodological approaches as well, LHs' focus on temporality, intra-household dynamics, household response pathways, and embedding individual actions in wider shifts are particularly useful.

At the level of policy and in common practice, certain assumptions and dominant narratives serve to shape how and what adaptation action is prioritised. Echoing Godfrey and Richardson (2004: 145), we argue that 'oral testimony tells us as much about the symbolic categories through which reality is constructed as it does about the 'facts' of people's lives'. Thus, the multiple narratives of intersecting climatic and non-climatic risks, dynamic vulnerability, and complex risk management decision-making that LHs capture serve to contest linear mono-causal understandings of vulnerability and unpack the seemingly black box of adaptation differentiation and decision-making. It also helps redress the tendency within policy discourse to focus exclusively on big $\mathrm{n}$ data as a way to justify and assess adaptation interventions. Such approaches marginalise issues central to vulnerability and adaptation such as intra-household well-being, gender relations, and changing aspirations (Rao et al. 2020) by reducing complexity.

Different methodologies privilege different facts and portrayals of the truth. To be truly representative and include marginal voices, CCVA research needs to expand current, dominant methodologies to capture these different understandings of risk and how they inform response behaviour. While we do not suggest privileging one methodological approach over the other, we call for recognising and capitalising on the strengths that different approaches bring to CCVA research and practice. Life histories, as we demonstrate in this paper, are one way to expand the range of existing methodological approaches employed and add immense value to who is represented and what is valued in CCVA research and practice. They allow us to challenge conventional assumptions about who is vulnerable and how strategies to deal with multiple risks follow dynamic, heterogeneous pathways. This expanded understanding of risk perception, and risk management behaviour (of which adaptation is one kind of response), we argue, has direct implications on the kinds of adaptation that gets supported, when and where interventions are made, and how they are incentivised.

Acknowledgements This work was supported by the Adaptation at Scale in Semi-Arid Regions (ASSAR), which is a consortium under the CARIAA programme of the International Development Research Centre (IDRC), and the UK Department for International Development (DFID). The views expressed in this work are those of the creators and do not necessarily represent those of DfID and IDRC or its Board of Governors. The paper especially benefitted from funding through ASSAR's Small Opportunities Grant and the South African Department of Science and Technology. We would also like to thank Catherine Locke for ideas and comments during initial stages of the paper and our respondents across Ghana, India, Kenya, and Namibia for sharing their life stories with us.

Open Access This article is distributed under the terms of the Creative Commons Attribution 4.0 International License (http:// creativecommons.org/licenses/by/4.0/), which permits unrestricted use, distribution, and reproduction in any medium, provided you give appropriate credit to the original author(s) and the source, provide a link to the Creative Commons license, and indicate if changes were made.

\section{References}

Adamson GCD, Hannaford MJ, Rohland EJ (2018) Re-thinking the present: the role of a historical focus in climate change adaptation research. Glob Environ Chang 48:195-205. https://doi.org/10.1016/j. gloenvcha.2017.12.003 
Adger WN (2006) Vulnerability. Glob Environ Chang 16:268-281. https://doi.org/10.1016/j.gloenvcha.2006.02.006

Adger WN (2010) Climate change, human well-being and insecurity. New Polit Econ 15:275-292. https://doi.org/10.1080/ 13563460903290912

Adger WN, Arnell NW, Tompkins EL (2005) Successful adaptation to climate change across scales. Glob Environ Chang 15:77-86. https://doi.org/10.1016/j.gloenvcha.2004.12.005

Arnall A, Kothari U (2015) Challenging climate change and migration discourse: different understandings of timescale and temporality in the Maldives. Glob Environ Chang 31:199-206. https://doi.org/10. 1016/j.gloenvcha.2015.01.011

Atkinson R (2002) The life story interview. Handb interview Res Context Method 121-140. https://doi.org/10.4135/9781412973588

Ayantunde AA, Turner MD, Kalilou A (2015) Participatory analysis of vulnerability to drought in three agro-pastoral communities in the West African Sahel. Pastor Res Policy Pract 5:13. https://doi.org/10. 1186/s13570-015-0033-x

Ayeb-Karlsson S, van der Geest K, Ahmed I, Huq S, Warner K (2016) A people-centred perspective on climate change, environmental stress, and livelihood resilience in Bangladesh. Sustain Sci 11:679-694. https://doi.org/10.1007/s11625-016-0379-z

Bagchi DK, Blaikie P, Cameron J, Chattopadhyay M, Gyawali N, Seddon D (1998) Conceptual and methodological challenges in the study of livelihood trajectories: case studies in eastern India and Western Nepal. J Int Dev 10:453-468

Bakewell O (2010) Some reflections on structure and agency in migration theory. J Ethn Migr Stud 36:1689-1708. https://doi.org/10.1080/ 1369183X.2010.489382

Baldwin A, Fornalé E (2017) Adaptive migration: pluralising the debate on climate change and migration. Geogr J 183:322-328. https://doi. org/10.1111/geoj.12242

Bardsley DK, Hugo GJ (2010) Migration and climate change: examining thresholds of change to guide effective adaptation decision-making. Popul Environ 32:238-262. https://doi.org/10.1007/s11111-0100126-9

Baumeister RF, Newman LS (1994) How stories make sense of personal experiences: motives that shape autobiographical narratives. Personal Soc Psychol Bull 20:676-690. https://doi.org/10.1177/ 0146167294206006

Bennett NJ, Blythe J, Tyler S, Ban NC (2016) Communities and change in the anthropocene: understanding social-ecological vulnerability and planning adaptations to multiple interacting exposures. Reg Environ Chang 16:907-926. https://doi.org/10.1007/s10113-0150839-5

Bettini G, Gioli G (2016) Waltz with development: insights on the developmentalization of climate-induced migration. Migr Dev 5: 171-189. https://doi.org/10.1080/21632324.2015.1096143

Biesbroek GR, Klostermann JEM, Termeer CJAM, Kabat P (2013) On the nature of barriers to climate change adaptation. Reg Environ Chang 13:1119-1129. https://doi.org/10.1007/s10113-013-0421-y

Bird K, Shinyekwa I (2005) Even the 'rich' are vulnerable: multiple shocks and downward mobility in rural Uganda. Dev Policy Rev 23:55-85. https://doi.org/10.1111/j.1467-7679.2005.00276.x

Birkmann J, Cutter SL, Rothman DS, Welle T, Garschagen M, van Ruijven B, O'Neill B, Preston BL, Kienberger S, Cardona OD, Siagian T, Hidayati D, Setiadi N, Binder CR, Hughes B, Pulwarty R (2015) Scenarios for vulnerability: opportunities and constraints in the context of climate change and disaster risk. Clim Chang 133: 53-68. https://doi.org/10.1007/s10584-013-0913-2

Bjurström A, Polk M (2011) Physical and economic bias in climate change research: a scientometric study of IPCC Third Assessment Report. Clim Chang 108:1-22. https://doi.org/10.1007/s10584-0110018-8

Blaikie P, Cannon T, Davis I, Wisner B (2004) At risk: natural hazards, people's vulnerability and disasters. Routledge, Abingdon
Bouroncle C, Imbach P, Rodríguez-Sánchez B, Medellín C, MartinezValle A, Läderach P (2016) Mapping climate change adaptive capacity and vulnerability of smallholder agricultural livelihoods in Central America: ranking and descriptive approaches to support adaptation strategies. Clim Chang 141:1-15. https://doi.org/10. 1007/s10584-016-1792-0

Burnham M, Ma Z (2017) Climate change adaptation: factors influencing Chinese smallholder farmers' perceived self-efficacy and adaptation intent. Reg Environ Chang 17:171-186. https://doi.org/10.1007/ s10113-016-0975-6

Butler JRA, Bohensky EL, Suadnya W, Yanuartati Y, Handayani T, Habibi P, Puspadi K, Skewes TD, Wise RM, Suharto I, Park SE, Sutaryono Y (2016) Scenario planning to leap-frog the sustainable development goals: an adaptation pathways approach. Clim Risk Manag 12:83-99. https://doi.org/10.1016/j.crm.2015.11.003

Campeanu CN, Fazey I (2014) Adaptation and pathways of change and response: a case study from Eastern Europe. Glob Environ Chang 28:351-367. https://doi.org/10.1016/j.gloenvcha.2014.04.010

Cannon T, Müller-Mahn D (2010) Vulnerability, resilience and development discourses in context of climate change. Nat Hazards 55:621635. https://doi.org/10.1007/s11069-010-9499-4

Castles S (2010) Understanding global migration: a social transformation perspective. J Ethn Migr Stud 36:1565-1586. https://doi.org/10. 1080/1369183X.2010.489381

Chimhowu A, Hulme D (2006) Livelihood dynamics in planned and spontaneous resettlement in Zimbabwe: converging and vulnerable. World Dev 34:728-750. https://doi.org/10.1016/j.worlddev.2005. 08.011

Clay N (2018) Integrating livelihoods approaches with research on development and climate change adaptation. Prog Dev Stud 18:1-17. https://doi.org/10.1177/1464993417735923

Cutter S (2003) The vulnerability of science and the science of vulnerability. Ann Assoc Am Geogr 93:1-12. https://doi.org/10.2307/ 973677

Davidson D (2016) Gaps in agricultural climate adaptation research. Nat Clim Chang 6:433-435. https://doi.org/10.1038/nclimate3007

Davies J, Singh C, Tebboth J, Spear D, Mensah A, Ansah P (2018) Conducting life history interviews: a how-to guide. ASSAR, University of Cape Town, South Africa, Cape Town

de Haan L, Zoomers A (2005) Exploring the frontier of livelihoods research. Dev Chang 36:27-47. https://doi.org/10.1111/j.0012-155X. 2005.00401.x

Djoudi H, Locatelli B, Vaast C, Asher K, Brockhaus M, Basnett Sijapati B (2016) Beyond dichotomies: gender and intersecting inequalities in climate change studies. Ambio 45:248-262. https://doi.org/10. 1007/s13280-016-0825-2

Eakin H, Winkels A, Sendzimir J (2009) Nested vulnerability: exploring cross-scale linkages and vulnerability teleconnections in Mexican and Vietnamese coffee systems. Environ Sci Pol 12:398-412. https://doi.org/10.1016/j.envsci.2008.09.003

Elder GHJ (1998) The life course as developmental theory. Child Dev 69: 1-12. https://doi.org/10.1111/j.1467-8624.1998.tb06128

Elder G (2012) Time, human agency, and social change: perspectives on the life course. Soc Psychol Q 57:4-15

Erel U (2007) Constructing meaningful lives: biographical methods in research on migrant women. Sociol Res Online 12:1-14. https://doi. org/10.5153/sro. 1573

Eriksen S, Aldunce P, Bahinipati CS et al (2011) When not every response to climate change is a good one: identifying principles for sustainable adaptation. Clim Dev 3:7-20. https://doi.org/10.3763/ cdev. 2010.0060

Farbotko C, McMichael C, Dun O, Ransan-Cooper H, McNamara KE, Thornton F (2018) Transformative mobilities in the Pacific: promoting adaptation and development in a changing climate. Asia Pacific Policy Stud 5:393-407. https://doi.org/10.1002/app5.254 
Fawcett D, Pearce T, Ford JD, Archer L (2017) Operationalizing longitudinal approaches to climate change vulnerability assessment. Glob Environ Chang 45:79-88. https://doi.org/10.1016/j.gloenvcha. 2017.05.002

Fazey I, Kesby M, Evely A, Latham I, Wagatora D, Hagasua JE, Reed MS, Christie M (2010) A three-tiered approach to participatory vulnerability assessment in the Solomon Islands. Glob Environ Chang 20:713-728. https://doi.org/10.1016/j.gloenvcha.2010.04.011

Ford JD, Keskitalo ECH, Smith T, Pearce T, Berrang-Ford L, Duerden F, Smit B (2010) Case study and analogue methodologies in climate change vulnerability research. Wiley Interdiscip Rev Clim Chang 1: 374-392. https://doi.org/10.1002/wcc.48

Füssel HM, Klein RJT (2006) Climate change vulnerability assessments: an evolution of conceptual thinking. Clim Chang 75:301-329. https://doi.org/10.1007/s10584-006-0329-3

Fussell E, Hunter LM, Gray CL (2014) Measuring the environmental dimensions of human migration: the demographer's toolkit. Glob Environ Chang 28:182-191. https://doi.org/10.1016/j.gloenvcha. 2014.07.001

Gajjar SP, Singh C, Deshpande T (2018) Tracing back to move ahead: a review of development pathways that constrain adaptation futures. Clim Dev 11:1-15. https://doi.org/10.1080/17565529.2018. 1442793

García de Jalón S, Silvestri S, Granados A, Iglesias A (2015) Behavioural barriers in response to climate change in agricultural communities: an example from Kenya. Reg Environ Chang 15:851-865. https:// doi.org/10.1007/s10113-014-0676-y

Geertz C (1973) Thick description. In: The interpretation of cultures. Basic Books, New York, pp 3-30

Gemenne F, Blocher J (2017) How can migration serve adaptation to climate change? Challenges to fleshing out a policy ideal. Geogr J 183:336-347. https://doi.org/10.1111/geoj.12205

Gerlitz J-YY, Macchi M, Brooks N, Pandey R, Banerjee S, Jha SK (2017) The Multidimensional Livelihood Vulnerability Index-an instrument to measure livelihood vulnerability to change in the Hindu Kush Himalayas. Clim Dev 9:124-140. https://doi.org/10.1080/ 17565529.2016.1145099

Granderson AA (2014) Making sense of climate change risks and responses at the community level: a cultural-political lens. Clim Risk Manag 3:55-64. https://doi.org/10.1016/j.crm.2014.05.003

Grothmann T, Patt A (2005) Adaptive capacity and human cognition: the process of individual adaptation to climate change. Glob Environ Chang 15:199-213. https://doi.org/10.1016/j.gloenvcha.2005.01. 002

Gupta J, Termeer C, Klostermann J, Meijerink S, van den Brink M, Jong P, Nooteboom S, Bergsma E (2010) The Adaptive Capacity Wheel: a method to assess the inherent characteristics of institutions to enable the adaptive capacity of society. Environ Sci Pol 13:459-471. https://doi.org/10.1016/j.envsci.2010.05.006

Hagemaster JN (1992) Life history: a qualitative method of research. J Adv Nurs 17:1122-1128. https://doi.org/10.1111/j.1365-2648.1992. tb02047.x

Hahn MB, Riederer AM, Foster SO (2009) The livelihood vulnerability index: a pragmatic approach to assessing risks from climate variability and change-a case study in Mozambique. Glob Environ Chang 19:74-88. https://doi.org/10.1016/j.gloenvcha.2008.11.002

Hegga S, Ziervogel G, Angula M, Spear D, Nyamwanza A, Ndeunyema E, Kunamwene I, Togarepi C, Morchain D (2016) Vulnerability and risk assessment in the Omusati region in Namibia: fostering peoplecentred adaptation to climate change. Cape Town

Howe PD, Yarnal B, Coletti A, Wood NJ (2013) The participatory vulnerability scoping diagram: deliberative risk ranking for community water systems. Ann Assoc Am Geogr 103:343-352. https://doi.org/ $10.1080 / 00045608.2013 .754673$
Hulme M (2008) Geographical work at the boundaries of climate change. Trans Inst Br Geogr 33:5-11. https://doi.org/10.1111/j.1475-5661. 2007.00289.x

Hulme M (2011) Commentary: meet the humanities. Nat Clim Chang 1: 177-179. https://doi.org/10.1038/nclimate1150

Hulme M, Dessai S, Lorenzoni I, Nelson DR (2009) Unstable climates: exploring the statistical and social constructions of "normal" climate. Geoforum 40:197-206. https://doi.org/10.1016/j.geoforum. 2008.09.010

Joakim EP, Mortsch L, Oulahen G (2015) Using vulnerability and resilience concepts to advance climate change adaptation. Environ Hazards 14:137-155. https://doi.org/10.1080/17477891.2014. 1003777

Jurgilevich A, Räsänen A, Groundstroem F, Juhola S (2017) A systematic review of dynamics in climate risk and vulnerability assessments. Environ Res Lett 12:013002. https://doi.org/10.1088/1748-9326/ aa5508

Kothari U, Hulme D (2004) Narratives, stories and tales: understanding poverty dynamics through life histories, pp 1-41

Langevang T (2008) "We are managing!" uncertain paths to respectable adulthoods in Accra, Ghana. Geoforum 39:2039-2047. https://doi. org/10.1016/j.geoforum.2008.09.003

Lewis D (2008) Using life histories in social policy research: the case of third sector/public sector boundary crossing. J Soc Policy 37:559578. https://doi.org/10.1017/S0047279408002213

Locke C, Lloyd-Sherlock P (2011) Qualitative life course methodologies: critical reflections from development studies. Dev Chang 42:11311152. https://doi.org/10.1111/j.1467-7660.2011.01728.x

Malone EL, Engle NL (2011) Evaluating regional vulnerability to climate change: purposes and methods. Wiley Interdiscip Rev Clim Chang 2:462-474. https://doi.org/10.1002/wcc.116

Massey DS, Arango J, Hugo G, Kouaouci A, Pellegrino A (1999) Worlds in motion: understanding international migration at the end of the millennium: understanding international migration at the end of the millennium. Clarendon Press, Oxford

McHugh KE (2000) Inside, outside, upside down, backward, forward, round and round: a case for ethnographic studies in migration. Prog Hum Geogr 24(1):71-89

Moezzi M, Janda KB, Rotmann S (2017) Using stories, narratives, and storytelling in energy and climate change research. Energy Res Soc Sci 31:1-10. https://doi.org/10.1016/j.erss.2017.06.034

Morchain D, Kelsey F (2016) Finding ways together. The vulnerability and risk assessment methodology, Oxford

Mortreux C, Barnett J (2017) Adaptive capacity: exploring the research frontier. WIREs Clim Chang 8:1-12. https://doi.org/10.1002/wcc. 467

Murray C (2002) Livelihoods research: transcending boundaries of time and space. J South Afr Stud 28:489-509. https://doi.org/10.1080/ 0305707022000006486

Neumann K, Hilderink H (2015) Opportunities and challenges for investigating the environment-migration nexus. Hum Ecol 43:309-322. https://doi.org/10.1007/s10745-015-9733-5

Ngigi MW, Mueller U, Birner R (2017) Gender differences in climate change adaptation strategies and participation in group-based approaches: an intra-household analysis from rural Kenya. Ecol Econ 138:99-108. https://doi.org/10.1016/j.ecolecon.2017.03.019

Nielsen JO, Reenberg A (2010) Temporality and the problem with singling out climate as a current driver of change in a small West African village. J Arid Environ 74:464-474. https://doi.org/10. 1016/j.jaridenv.2009.09.019

Nyantakyi-Frimpong H, Bezner-Kerr R (2015) The relative importance of climate change in the context of multiple stressors in semi-arid Ghana. Glob Environ Chang 32:40-56. https://doi.org/10.1016/j. gloenvcha.2015.03.003

O’Brien K, Leichenko R, Kelkar U, Venema H, Aandahl G, Tompkins H, Javed A, Bhadwal S, Barg S, Nygaard L, West J (2004) Mapping 
vulnerability to multiple stressors: climate change and globalization in India. Glob Environ Chang 14:303-313. https://doi.org/10.1016/ j.gloenvcha.2004.01.001

Obokata R, Veronis L, McLeman R (2014) Empirical research on international environmental migration: a systematic review. Popul Environ 36:111-135. https://doi.org/10.1007/s11111-014-0210-7

Osbahr H, Twyman C, Neil Adger W, Thomas DSG (2008) Effective livelihood adaptation to climate change disturbance: scale dimensions of practice in Mozambique. Geoforum 39:1951-1964. https:// doi.org/10.1016/j.geoforum.2008.07.010

Paschen JA, Ison R (2014) Narrative research in climate change adaptation - exploring a complementary paradigm for research and governance. Res Policy 43:1083-1092. https://doi.org/10.1016/j.respol. 2013.12.006

Piguet E (2010) Linking climate change, environmental degradation, and migration: a methodological overview. Wiley Interdiscip Rev Chang 1:517-524. https://doi.org/10.1002/wcc.54

Piguet E, Kaenzig R, Guelat J (2018) The uneven geography of research on "environmental migration". Popul Environ 39:357-383. https:// doi.org/10.1007/s11111-018-0296-4

Punch S, Sugden F (2013) Work, education and out-migration among children and youth in upland Asia: changing patterns of labour and ecological knowledge in an era of globalisation. Local Environ 18:255-270. https://doi.org/10.1080/13549839.2012. 716410

Ransan-Cooper H (2016) The role of human agency in environmental change and mobility: a case study of environmental migration in Southeast Philippines. Environ Sociol 1042:1-12. https://doi.org/ 10.1080/23251042.2016.1144405

Rao N (2014) Caste, kinship, and life course: rethinking women's work and agency in Rural South India. Fem Econ 20:78-102. https://doi. org/10.1080/13545701.2014.923578

Rao N, Lawson ET, Raditloaneng WN, Solomon D, Angula MN (2017) Gendered vulnerabilities to climate change: insights from the semiarid regions of Africa and Asia. Clim Dev 11:1-13. https://doi.org/ $10.1080 / 17565529.2017 .1372266$

Rao N, Singh C, Solomon D, Camfield L, Sidiki R, Angula M, Poonacha P, Sidibé A, Lawson ET (2020) Managing risk, changing aspirations and household dynamics: Implications for wellbeing and adaptation in semi-arid Africa and India. World Development, 125, 104667. https://doi.org/10.1016/j.worlddev.2019.104667

Ravera F, Iniesta-Arandia I, Martín-López B, Pascual U, Bose P (2016) Gender perspectives in resilience, vulnerability and adaptation to global environmental change. Ambio 45:235-247. https://doi.org/ $10.1007 / \mathrm{s} 13280-016-0842-1$

Ray D (2006) Aspirations, poverty, and economic change. Underst Poverty. https://doi.org/10.1093/0195305191.003.0028

Ribot J (2014) Cause and response: vulnerability and climate in the Anthropocene. J Peasant Stud 6150:1-39. https://doi.org/10.1080/ 03066150.2014 .894911

Rigg J (2006) Land, farming, livelihoods, and poverty: rethinking the links in the Rural South. World Dev 34:180-202. https://doi.org/ 10.1016/j.worlddev.2005.07.015

Rivers L III, Sanga U, Sidibe A, Wood A, Paudel R, Marquart-Pyatt ST, Ligmann-Zielinska A, Olabisi LS, Du EJ, Liverpool-Tasie S (2018) Mental models of food security in rural Mali. Environ Syst Decis 38: 33-51. https://doi.org/10.1007/s10669-017-9669-y

Rogaly B, Coppard D (2003) "They used to go to eat, now they go to earn": the changing meanings of seasonal migration from Puruliya District in West Bengal, India. J Agrar Chang 3:395-433. https://doi. org/10.1111/1471-0366.00060

Roy M, Venema HD (2002) Reducing risk and vulnerability to climate change in India: the capabilities approach. Gend Dev 10:78-83. https://doi.org/10.1080/13552070215904
Sallu SMS, Twyman C, Stringer LCL (2010) Resilient or vulnerable livelihoods? Assessing livelihood dynamics and trajectories in rural Botswana. Ecol Soc 15:3

Scheibelhofer E (2017) Shifting migration aspirations in second modernity. J Ethn Migr Stud 9451:1-15. https://doi.org/10.1080/ 1369183X.2017.1384151

Sen A (1981) Poverty and famines: an essay on entitlement and deprivation. Oxford University Press, Oxford

Shucksmith M, Brown DL, Argent N et al (2016) Migration and the life course in rural settings. In: Routledge international handbook of rural studies. Routledge, Abingdon, pp 36-49

Singh C (2018) Using life histories to understand temporal vulnerability to climate change in highly dynamic contexts. SAGE Res Methods Case. https://oi.org/10.4135/9781526440358

Singh C (2019) Migration as a driver of changing household structures: implications for household livelihoods and adaptation. Migration and Development. https://doi.org/10.1080/ 21632324.2019.1589073

Singh C, Basu R (2019) Moving in and out of vulnerability: interrogating migration as an adaptation strategy along a rural urban continuum in India. The Geographical Journal. https:// doi.org/10.1111/geoj.12328

Singh C, Basu R, Srinivas (2016a) Livelihood vulnerability and adaptation in Kolar District, Karnataka, India: Mapping risks and responses. ASSAR Short Report. Available at: http://www.assar.uct. ac.za/sites/default/files/image tool/images/138/South Asia/ Reports/Kolar\%20Focus\%20Group\%20Discussions\%20-\% 20Short\%20Report\%20-\%20July\%202016.pdf

Singh C, Dorward P, Osbahr H (2016b) Developing a holistic approach to the analysis of farmer decision-making: implications for adaptation policy and practice in developing countries. Land Use Policy 59: 329-343. https://doi.org/10.1016/j.landusepol.2016.06.041

Singh C, Deshpande T, Basu R (2017) How do we assess vulnerability to climate change in India? A systematic review of literature. Reg Environ Chang 17:527-538. https://doi.org/10.1007/s10113-016-1043-y

Suckall N, Fraser E, Forster P (2016) Reduced migration under climate change: evidence from Malawi using an aspirations and capabilities framework. Clim Dev 5529:1-15. https://doi.org/10.1080/ 17565529.2016.1149441

Tanner T, Lewis D, Wrathall D, Bronen R, Cradock-Henry N, Huq S, Lawless C, Nawrotzki R, Prasad V, Rahman MA, Alaniz R, King K, McNamara K, Nadiruzzaman M, Henly-Shepard S, Thomalla F (2014) Livelihood resilience in the face of climate change. Nat Clim Chang 5:23-26. https://doi.org/10.1038/nclimate2431

Thompson-Hall M, Carr ER, Pascual U (2016) Enhancing and expanding intersectional research for climate change adaptation in agrarian settings. Ambio 45:373-382. https://doi.org/10.1007/s13280-0160827-0

Thomson R, Bell R, Holland J, Henderson S, McGrellis S, Sharpe S (2002) Critical moments: choice, chance and opportunity in young people's narratives of transition. Sociology 36:335-354. https://doi. org $/ 10.1177 / 0038038502036002006$

Tschakert P, van Oort B, St. Clair AL, LaMadrid A (2013) Inequality and transformation analyses: a complementary lens for addressing vulnerability to climate change. Clim Dev 5:340-350. https://doi.org/ 10.1080/17565529.2013.828583

van Aalst MK, Cannon T, Burton I (2008) Community level adaptation to climate change: the potential role of participatory community risk assessment. Glob Environ Chang 18:165-179. https://doi.org/10. 1016/j.gloenvcha.2007.06.002

van der Linden S (2015) The social-psychological determinants of climate change risk perceptions: towards a comprehensive model. J Environ Psychol 41:112-124. https://doi.org/10.1016/j.jenvp.2014.11.012

van Valkengoed A, Steg L (2019) Meta-analyses of factors motivating climate change adaptation behaviour. Nature Climate Change 9(2). https://doi.org/10.1038/s41558-018-0371-y 
Varadan RJ, Kumar P (2015) Mapping agricultural vulnerability of Tamil Nadu, India to climate change: a dynamic approach to take forward the vulnerability assessment methodology. Clim Chang 129:159181. https://doi.org/10.1007/s10584-015-1327-0
Wimark T, Lewis NM, Caretta MA (2017) A life course approach to the field and fieldwork. Area. 49:390-393. https://doi.org/10.1111/area.12362

Publisher's note Springer Nature remains neutral with regard to jurisdictional claims in published maps and institutional affiliations. 